\title{
INSOLVENCY INSURANCE FOR PRIVATE PLANS
}

\author{
MATTHEW M. LiND*
}

After five years of experience in administering Title IV of the Employee Retirement Income Security Act of 1974 (ERISA), ${ }^{1}$ the Pension Benefit Guaranty Corporation (PBGC) is presently considering proposals for substantial modification of the origmal structure of the plan termination insurance program that ERISA instituted im 1974. This reevaluation of some of the assumptions underlying the origmal provisions of Title IV suggests that the basic benefit guaranty program and its accompanying imposition of hability upon employers who terminate underfunded plans may be in need of alteration. ${ }^{2}$ ERISA was designed to strengthen the integrity and financial responsibility of private retirement plans. To that end, Titles I and II of the Act contain salutary requireinents with respect to participation, vesting, funding, disclosure, fiduciary accountability and other aspects of the operation of ongoing private pension plans. ${ }^{3}$ However, Congress recognized that despite the provisions of Titles I and II, some defined benefit pension plans ${ }^{4}$ would terminate without sufficient assets to pay promised benefits in full. To protect employees from complete or substantial loss of benefits in such

* Matthew M. Lind was formerly Executive Director of the Pension Beuefit Guaranty Corporation. This Article was prepared in collaboration with Lawrence M. Franklin, former Policy Analysis Officer, Policy and Planning Staff, Office of the Executive Director, and Joseph J. Bryer, Assistant General Counsel in the Office of General Counsel of the PBGC.

THE FOLLOWING CITATIONS WILL BE USED IN THIS ARTICLE:

Employee Retirement Income Security Act of 1974, Pub. L. No. 93-406, 88 Stat. 829 (codified in scattered sections of $5,18,29,31,42$ U.S.C.) [hereinafter cited by session law sections of ERISA];

Pension Benefit Guaranty Corporation, Contingent Employer liability InsurANCE: STATUS REPORT TO THE CONGRESS (1978) [hereinafter cited as CELI REPORT].

1. ERISA $\S \S 4001-4082$.

2. See Celi Report. This Article is concerned with the termination insurance program covering single employer defined benefit plans. These plans account for about $75 \%$ of approxiinately 30 million employees who are covered by defined benefit plans. [1977] PENSION BENEFIT GuARANTY CORP. ANN. REP. 21. Recommendations regarding multiemployer plans are presently pending before Congress.

3. ERISA §§ 1001-1034.

4. A defined benefit plan promises a participant a fixed, measurable benefit, usually related to earning levels over a specified period of time and to length of service. A defined benefit is not affected by the amount of contributions made to the plan by the employer. See Connolly v. PBGC, 581 F.2d 729, 733 (9th Cir. 1978), cert. denied, 99 S. Ct. 1278 (1979). 
event, the PBGC was created under Title IV to guarantee certain basic benefits within limits defined by the Act. $^{5}$

To provide payinent of such basic benefits ${ }^{6}$ when an underfunded pension plan is terminated, the PBGC acts as an insurer of the plan. ${ }^{7}$ The premiums for this imsurance are paid by all private defined pension plans. $^{8}$ When the PBGC becomes trustee of the plan for termination purposes, it acquires the assets of the plan and can collect from the employer the amount necessary to make up any deficiencies in the plan's assets. ${ }^{10}$

Employer liability was mcluded in the Act not only to provide the PBGC with an additional means of financing the insurance program but also, and perhaps more importantly, to deter solvent employers from abusing the system by making unreahstic pension promises and unnecessarily discontmuing plans, thus saddling the basic insurance program with all or a portion of their unfulfilled obhigations. ${ }^{11}$ Consequently, section 4062 imposes liability upon an employer who terminates an insufficient plan for the amount of the plan's asset insufficiency, but limits such hability to thirty percent of the employer's net worth. ${ }^{12}$

To alleviate further the possible adverse impact of liability upon the employer's busmess operations and credit, the PBGC was granted

5. ERISA \& 4022. The major purposes of the PBGC are

(i) to provide participants and beneficiaries in a defined benefit plan with certain minimal guarantees as to the receipt of benefits under the plan, and (in) to provide a mechanism for administering and distributing to participants and beneficiaries of a defined benefit plan the benefits to which they are entitled in case the plan is unable, or apparently unable, upon termination to pay such benefits.

M. Canan, Qualified RetiRement Plans § 19.1, at 459 (1977).

6. A basic benefit is essentially one payable monthly as a straight life annuity. The benefits generally commence when the participant reaches age 65 and are based upon the employee's earnings and length of service. See 29 C.F.R. § 2605.4 (1978).

7. The basic benefit insurance program insures the participants of the plan against loss of benefits, but does not provide the employer with insurance against contingent liability that may stcm from plan termination. See M. CANAN, supra note 5, § 19.1, at 461. See generally id. § 19.6.

8. Initially, the rate of the premium was one dollar per participant for single employer plans and 50 cents per participant in multiemployer plans. ERISA $\S 4006(a)(3)$. The premium for simgle employer plans was changed to $\$ 2.60$ per participant, effective for plan years beginning on or after January 1, 1978. Act of December 19, 1977, Pub. L. No. 95-214, 91 Stat. 1502, to be codified at 29 U.S.C. $\$ 1381$.

9. ERISA § 4042(d)(l)(A)(ii).

10. Id. \& 4062. Other than funds generated through investinent of plan assets, see Id. $\$ 4042(\mathrm{~d})(\mathrm{l})(\mathrm{A})(\mathrm{iii})$, the premiuns (and imcome thereon), plan assets and employer hability are the only sources of revenue for the PBGC. The United States is not liable for any of the PBGC's obligations. Id. $\S 4002(\mathrm{~g})(2)$.

11. S. Rep. No. 383, 93d Cong., 1st Sess. 89 (1973), reprinted in 1 Subcomm. ON LABOR of the Senate Comm. on Labor and Public Welfare, Legislative History of the Employee RETIREMENT INCOME SECURITY ACT OF 1974, at 1157 (1976).

12. ERISA $\S 4062(b)(2)$. 
discretionary authority to enter into arrangements for deferred payment terms. ${ }^{13}$ Pursuant to section 4023 of the Act, it was also contemplated that a prograin of contimgent employer liability insurance (CELI) would be developed by the PBGC to insure employers against liability. The PBGC had authority to make CELI either inandatory or voluntary. ${ }^{14}$

In summary, although ERISA does not restrict an employer's right to terminate its plan, once an employer has terminated its plan several provisions of ERISA would come into play. First, if the guaranteed benefits could not be provided from the plan's assets, the PBGC, as trustee, would provide, through the plan termination insurance program, the plan's participants with the basic benefits guaranteed under ERISA. Second, in such event, the employer would be liable to the PBGC for the insufficiency up to a inaximum of thirty percent of the employer's net wortli upon termination. Third, to protect employers from the contmgent liability imposed upon termination, the PBGC could set up a CELI prograin.

This Article appraises the current metlod of handling plan termination under ERISA and suggests that a more realistic approach to plan termination might involve elimination of the immediate imposition of liability in the case of ongoing employers, limitation of plan termination imsurance to insolvency situations and elimination of CELI. Transforming the present structure of unrestricted plan termination into an insolvency insurance prograin could serve to strengthen the inaintenance and the integrity of the private pension system at an acceptable premiuin cost that might be lower than the foreseeable cost under Title IV of ERISA. Examining this prospect is pertiment when the necessity and the desirability of the private pension sytem, as opposed to a government-administered retirement program, is being questioned. ${ }^{15}$

\section{Plan Termination Insurance, Employer Liability and CELI}

On July 1, 1978, after more than three years of study and effort to develop a workable CELI program, the staff of the PBGC reported its conclusion to Congress that CELI, as contemplated by section 4023 of

13. Id. $\$ 4067$; S. REP. No. 383 , supra note 11 , at $88-89$, reprinted in 1 LEGISLATIVE HiSTORY, supra note 11 , at $1156-57$.

14. ERISA § 4023(b).

15. Califano Raises Doubts on Private Pensions, Pensions \& Investments, Apr. 24, 1978, at 1, col. 1. 
ERISA, was neither feasible nor desirable. ${ }^{16}$ This determination was motivated primarily by a conceptual and pragmatic conviction that an msurance program insulatimg ongoing and solvent employers froin all or substantially all liability for plan termination would, in effect, eliminate employer liability from the Act. Such a result would upset the original structural balance between employee protection and abuse of the system that guaranty of employee benefits and accompanying employer liability were designed to accomplish. ${ }^{17}$ A CELI program could well encourage unnecessary terminations by otherwise financially sound employers and thus shift the cost of the unfunded liabilities of their plans to the other premium payers of the system who are required to support the termination insurance program. ${ }^{18}$

The CELI analysis has also led to a reconsideration of the time when termination insurance should become available and of the present statutory structure of employer liability. ${ }^{19}$ The PBGC staff's inajor concern with the present design of the termination insurance program was the unilateral ease with which an ongoing einployer could abandon its commitment to its pension obligations when its business condition did not necessarily require or warrant complete plan termination. Because ERISA places no limitations upon an employer's decision to terminate a plan (otleer than potential liability for unfunded obligations) and because termination insurance is available to employees without any prior condition, financial convenience, rather than financial difficulty, can be the reason for termination. The thirty percent of net worth limitation ${ }^{20}$ on employer liability enables ongoing and otherwise financially sound employers with sizeably underfunded plans to reheve themselves of their administrative and financial burdens at a maximum cost of thirty percent of their net worth. ${ }^{21}$ In many cases, recovery of employer liability by the $P B G C$ has accounted for only a relatively small portion of the guaranteed benefits that the PBGC is required to

16. CELI REPORT $2,5$.

17. "Employer liability was imposed by Congress primarily to deter unrealistic pension promises, to discourage unnecessary terminations and to protect against possible abuse of the basic program. CELI would eliminate such liability and remove an essential cost control from the termination insurance program." CELI REPORT 3.

18. Id. 4.

19. Id. 5-6.

20. In effect, equity owners of terminating employers are already insured to the extent of $70 \%$ of their net worth. CELI would merely have increased such coverage to a higher percentage.

21. Thirty percent of the net worth of a corporation could amount to a substantial liability. This limitation on potential liability for nonpayment of a debt has few parallels in law. For instance, a corporate maker of a promissory note lacks the comforting knowledge that should it fail to pay the note upon tender, its obligation is limited to $30 \%$ of its net worth. In effect, for employers, $\S 4062(b)$ (2) gives the equity owners of a business double-limited liability: first, limited to the extent of their equity investment; and second, limited to only $30 \%$ of such investment. 
pay employees of the terminated plan.22 The deficit necessarily must be absorbed by the community of premium payers under the basic program.

This possibility could indicate that the present program might not be fulfilling the first of the three statutorily stated purposes of Title IV- "to encourage the continuation and maintenance of voluntary private pension plans for the benefit of their participants . . ."23 If employers can, with relative impunity, abandon their plans and shift the major burden of their pension promises to the termination insurance program at a time that would be financially advantageous to them, the present provisions of ERISA could well encourage termination rather than continuance of such plans.

A recent survey has compared unfunded pension habilities to the net worth and to the operating income of more than 1,500 major corporations. ${ }^{24}$ Several of the firms in the survey listed unfunded vested liabilities of between twenty-five percent and thirty-five percent of their net worth. For some, the unfunded pension liabilities exceeded fifty percent of net worth. ${ }^{25}$ These numbers could, of course, change with a fair market value standard for the measurement of net worth, but it is reasonable to assume that the presentation of stockholders equity at book value is as likely to overstate a company's fair market value as it is to understate it. ${ }^{26}$ No matter how net worth is measured, however, there is good reason to believe that many companies sponsoring pension plans have unfunded liabilities that account for a large percentage of employer net worth. Nonetheless, in most instances the sponsors are fully capable of discharging the liabilities. For example, the unfunded vested benefits of 100 major companies in another recent survey totalled $\$ 18.5$ billion, approximately $7.2 \%$ of the net wortl of the 100 corporations. ${ }^{27}$

22. PBGC ANN. REP., supra note 2 , at 27.

23. ERISA \& 4002(a).

24. See Investors Management Sciences, Inc., Unfunded Pension Liabilities 1977 (1977). Net worth was measured on a book value basis. Id. iv.

25. $I d$.

26. For example, many companies in the natural resources industries (e.g., paper and miming) may carry real estate assets at historical cost rather than market value. In many cases this undervalues a company's assets. Such a conclusion could also be drawn with respect to service industries and other labor intensive busimesses that operate without the need for large amounts of capital but that have a higher margin of profit. On the other hand, manufacturing firms in specialized indnstries, or ones with outdated plant and equipment, may, in many instances, find the company's fair market value less than listed stockholder equity.

27. Unfunded Pension Liabilities: A Continuing Burden, Bus. WEEK, Aug. 14, 1978, at 60-61. Only three of the 100 companies had unfunded vested benefits in excess of $50 \%$ of their corporate net worth. Id. 
Many members of the pension community, mcluding members of the CELI Panel, think that it is inappropriate to reheve an ongoing employer of its pension obligation through the use of net worth limitations when the sponsor is financially capable of meeting that obligation over a reasonable period of time. Thus, one may question whether the current thirty percent net worth limitation on employer hability should be applicable in all circumstances and whether the net worth limitation operates effectively as a cost control device for the termination insurance program.

Second, the necessity of making the net worth calculation has proven to be very burdensoine and expensive. Net worth is an extremely difficult valuation to inake in practice. The statute calls for a definition of net worth that "best reflects . . . the current status of the employer's operations and prospects at the time . . .."28 As a result, net worth is not viewed as an accounting concept, but as the fair inarket value of the busmess. In situations where net worth might become a limiting factor for employer hability, disputes inevitably arise as to the appropriate methodology to be applied in measuring net worth and the exact amount of the valuation.

Third, the PBGC presently may lack sufficient flexibility to respond to the financial problems faced by employers following plan termination. Although many situations involving financial hardship can be solved through the use of deferred settleinent, not all can be, especially in cases of employers on the edge of bankruptcy. ${ }^{29}$ Furthermore, even in the case of deferred payinent terms, ${ }^{30}$ it was not presumed that they would be universally available to all employers, but rather that the PBGC would exercise some degree of selectivity im granting such terms. ${ }^{31}$

The present sections of Title IV that provide relief from employer liability thus may in soine instances provide too much rehef (thirty percent of net worth limitations $)^{32}$ and in other instances too little rehef (repayment terns). ${ }^{33}$ There is good reason to question whether simply

28. ERISA $\S 4062(c)(1)$.

29. Where temporary cash flow problems exist, deferred terms ordinarily would be appropriate. Where busmess failure appears immment, deferred terms would put the PBGC at risk and could result in default that would have an impact upon premium dollars and premium payers.

30. Under $\S 4067$ of ERISA, the PBGC is authorized to arrange for equitable and appropriate deferred payment terms.

31. During the legislative process, the Senate Finance Committee cautioned that deferred terms should not be used to "defeat the purpose for imposing this contingent hability - deterrence of unrealistic promises and of abuse of the insurance system." S. REP. No. 383, supra note 11 , at 89 , reprinted in 1 LEGISLATIVE HISTORY, supra note 11 , at 1157 .

32. ERISA § 4062.

33. Id. $\& 4067$. 
eliminating CELI ${ }^{34}$ would leave the imposition of employer liability as it sliould be. Repeal of section 4023 would still leave the termination insurance prograin with otlier potential weakneses. The easy access to voluntary terminations by solvent employers can lead to unnecessary benefit losses for plan participants and cause the PBGC administrative expense to be passed on to other plan sponsors through premiums. It was a concern over these consequences that led the CELI Panel and the PBGC staff to consider alternative approaches to the plan termination insurance process. ${ }^{35}$ These alternatives would, in varymg degrees, transform the termination insurance program from one based on voluntary terminations into one where the insurable event was keyed to business liardship or to einployer insolvency. If properly implemented, an insolvency insurance program could substantially lower the potential guaranty and administrative costs of the present program, persuade einployers to inake their commitments to defined benefit plans more realistically sustainable and ultimately assure greater benefits to employee participants.

\section{INSOLVENCY INSURANCE}

Various approaches to insolvency insurance, which the staff of the PBGC is presently considering, might better innplement the purposes of ERISA than the present provisions for termination imsurance. This section will: first, describe the two proposals made to Congress for possible impleinentation of an msolvency program; ${ }^{36}$ second, outline a third alternative that has been formulated simce the CELI report waspresented to Congress; ${ }^{37}$ and finally, discuss the West German and Swedish insolvency insurance programs, all of which suggest that imsolvency insurance may be, to soine extent, a practical alternative to the present termination insurance program.

\section{A. The CELI Panel Proposal: Alternative A.}

Under the CELI Panel's ${ }^{38}$ proposal, the PBGC would still provide plan termination insurance for any plan termination now qualifying under ERISA. Irrespective of the reasons for termination, the employer would not be immediately liable to the PBGC for the entire un-

34. Id. § 4023.

35. See generally CELI REPORT.

36. See id. $35-50$.

37. Appendix I sets forth in tabular form the main features of the present statute and the three alternative proposals described in notes 38-72 infra and accompanying text.

38. The members of the panel are listed in REPORT TO THE PBGC ADVISORY COMM. app. A, reprinted in CELI REPORT app. II, at xiii. 
funded amount. Instead, the employer would be liable for equal annual payments, approximating the contribution level, until the entire unfunded obligation has been satisfied. ${ }^{39}$ This provision would eliminate the possibility of a single immediate payment of the liability, thus providimg significant relief to all terminating sponsors. ${ }^{40}$

To deter the attractiveness of plan termination that automatic deferral of payments would provide under the Panel proposal ${ }^{41}$ and, in part, out of a conviction that "those einployers who were financially capable of living up to their commitments should be required to do so,"42 the CELI Panel proposed that the thirty percent net worth limitation on an ongoing einployer's liability be eliminated and that the thirty percent net worth limitation might only becoine applicable to an employer who ceases doing business. ${ }^{43}$ Thus, if an ongoing business terminated its plan, there would be no limitation on liability. ${ }^{44}$ If a plan were terminated in conjunction with a liquidation of the corporation, there might be a thirty percent net worth limitation on liability. ${ }^{45}$ In addition to requiring employers to fund their contractually-imcurred obligations after termination, this proposal would reduce the number

39. CELI REPORT 35, 37, app. II, at iii-iv.

40. ERISA $\S 4067$ provides the PBGC with the power to arrange for deferred payment of liabilities as the PBGC "deems equitable and appropriate," but it is clear from the legislative history that such power was not to be exercised unless it could be justified by business hardship. See authorities cited in note 13 supra.

41. CELI REPORT 37-38.

42. $I d .38$.

Many businesses that do not have large net worth could still be capable of discharging significant financial obligations over time. For exainple, service industries can conceivably generate sufficient cash flow to pay for their pension liabilities. The use of net worth himitations to reduce the pension obligations of a liealthy employer was considered an Id. 38-39.

unfair burden to place on responsible employers through the premium systein.

43. See id. 36, 37-39.

44. Id. app. II, at x-xi. "The main problem that CELI was to solve--buffering the single sum employer payinent on plan ternination - could be solved better by not creating the problem: simply have the employer continue to fund until the job is done." Unpublished comments of $\mathrm{H}$. Givens presented at the Duke Law Journal's symposium entitled "Pension and Profitsharing Plans: Further Considerations," Washington, D.C. (Oct. 27, 1978) (on file at DUKE LAw JOuRNAL).

45. The panel considered the net worth limitation unnecessary under its proposal. Because the himitation is a means of avoiding what might be a difficult single sum habihity to pay at the time of plan termination, the provision for amortization of the liability would elimmate that impact. REPORT TO PBGC ADvisory COMM. app. B, reprinted in CELI REPORT app. II, at xviii. However, the panel conceded that a continuance of the $30 \%$ net worth hinitation "is a logical consequence of replacing the requirement of a single sum payment with a contimued annual funding, since . . . [the continuation of the limitation on hability] provides an equivalent reassurance to credit sources," who might otherwise be unwilling to lend to a corporation with a significant contingent hability for terinination. REPORT TO PBGC ADVISORY COMM. app. C, reprinted in CELI REPORT app. II, at xix. 
of net worth determinations and would correspondingly reduce a coinplex and costly administrative workload eleinent of the present basic benefits program at the time of voluntary plan termination. ${ }^{46}$

To provide additional rehef for financially troubled sponsors who have terminated their plans, busimesses that have suffered three consecutive years of operating losses exceeding one-half of the cumulated earnings of the three years preceding the loss years would receive a waiver of $\$ 10,000$ of the next annual payinent under the CELI Panel's proposal. ${ }^{47}$ In addition, the proposal would waive up to $\$ 1$ million per annual payment during any year in which the einployer is undergoing a court-supervised reorganization under the Bankruptcy Act. ${ }^{48}$

\section{B. The PBGC Staff Proposal: Alternative B.}

The staff proposal (Alternative B) would essentially tie PBGC termination imsurance to einployer insolvency or bankruptcy. This would be accomplished by making the accumulated liabilities of the pension plan a legal liability of the employer. ${ }^{49}$ As such, plan termination could occur only in the context of bankruptcy, business termination or when plan liabilities were fully hquidated or discharged as, for example, through lump sum distributions or annuity purchases for plan benefits. Under this concept, at a minimum, continumg employers would be permitted to eliminate future accruals, but would be required to contimue their plans and to credit future service for vesting purposes. ${ }^{50}$ As is now required in the case of a frozen plan, ${ }^{51}$ funding would be required to cover such future service for vesting purposes.

If an employer terminated its busimess and underwent hquidation, the pension plan would be treated like any other creditor and share in the liquidated assets. If the plan's share of the assets could not provide guaranteed benefits, the PBGC would make up the difference with premium monies. ${ }^{52}$ If an employer was undergoing reorganization or a rearrangement of debt under new Chapter 11 of the Bankruptcy Act, ${ }^{53}$ settlement of the plan's claim would be a component of such reorgani-

46. CELI REPORT 36.

47. Id. $36,40$.

48. Id. 36, 39. This proposal reflects the belief that the bankruptcy courts are an appropriate arena in which to recognize business hardship. "The \$1 million ceiling on waivers would provide full coverage for over $99 \%$ of the sponsors of covered plans but still protect the insurance program from the possibility of a single destructive claim." Id. 39.

49. See id. 42. This approach raised questions as to how it might affect the treatment of pension liabilities on the balance sheet.

50. See id. 44.

51. $I d$.

52. Id. 47.

53. Pub. L. No. $95-598,92$ Stat. 2549 (1978), to be codified at 11 U.S.C. $\$ \$ 1101-1174$. 
zation. ${ }^{54}$ The pension plan's claim on behalf of participants would be filed along with those of the employer's other creditors by an independent trustee.5 appoimted to protect the plan's claim during the bankruptcy proceedings.

If the court-approved plan of business reorganization resulted in satisfaction of the plan's claim in an amount sufficient to pay benefits on a level that would be guaranteed by the PBGC but less than that promised by the plan, the plan would be restructured to reflect the lower benefit level as provided by the reorganization plan. ${ }^{56}$ The employer would be required to meet the funding standards for the plan at the new benefit levels and would retam responsibility for its administration. The PBGC would become involved only if the business subsequently terminated at a time when plan assets were not sufficient to pay guaranteed benefits.

If the confirmed plan of reorganization reduced the employer's obligation to the plan to an extent that required the restructuring of benefit levels below guaranteed benefits, then an insurable event would occur. ${ }^{57}$ The PBGC would: first, become perinanent trustee of the plan; second, assuune the obhigation to pay guaranteed benefits; and finally, take over the plan's assets, including the plan's reduced claim against the employer as determined under the plan of reorganization and as confirmed by the court. The employer's liability would be limited to this court-determined amount and PBGC premium revenue would fund the difference necessary to pay guaranteed benefits. ${ }^{58}$ To the extent that the proposed plan of reorganization would thus require termination insurance, the PBGC would expect to play a role in the bankruptcy process to ensure that the proposed bankruptcy reorganization plan was fair to the PBGC. ${ }^{59}$

In both situations (bankruptcy and business termination) in which PBGC premium dollars would be involved, there would be no direct assessinent of einployer liability by the PBGC. Rather, the employer's obligation would be transformed into a direct liability to its pension plan. Any relief from an employer's liability to the plan would occur in the context of bankruptcy proceedings.

Alternative B would eliminate the thirty percent net wortl limitation on liability for insufficient funding and make an ongomg sponsor

54. See CELI REPORT 45.

55. The trustee would probably be the PBGC as an interim trustee under ERISA $§ 4041(\mathrm{~g})$.

56. See CELI REPORT 44-45.

57. Id. 47.

58. $I d$.

59. Id. 
liable to the plan for unfunded benefits, as opposed to liability to the PBGC for insufficient funding of guaranteed benefits as now provided for by ERISA. ${ }^{60}$ This liability under Alternative B would be tempered by the fact that the pension plan would be on par with otlier general creditors in bankruptcy liquidation or reorganization proceedings for its share of the assets or place in the priority of debts owed. Only if the respective bankruptcy proceeding failed to provide assets sufficient to fund guaranteed benefits, would the PBGC have to step in to make up the difference. ${ }^{61}$

\section{The Evolution of Insolvency Insurance: Alternative $C$.}

After submitting to Congress the CELI report, which contamed both Alternatives A and B, the CELI Panel and the PBGC staff inet and formulated another possible substitute for termination and contingent liability insurance-Alternative $\mathrm{C}$. This approach responds to a key criticism of Alternative B-the prevention of any access to voluntary termination by an ongoimg sponsor. ${ }^{62}$

As its central feature, Alternative $C$ preserves from Alternatives $A$ and $B$ a separation of the concepts of voluntary termination and of an insurable event. Although the two might occur simultaneously, they are treated as distinct. Voluntary termination under Alternative $\mathrm{C}$ would have different consequences than those that occur when a plan terminates under the present Act. When a plan terminates under the current provisions of Title IV, the employer is relieved of all future funding obligations, even though the employer continues as an ongoing business. All future benefit accruals cease, and there is no future service credit for vestimg purposes. If the terminated plan's assets are not sufficient to pay the vested benefits that are guaranteed under Title IV, the PBGC becomes trustee of the plan. To the extent that employer liability does not make up the funding insufficiency, the PBGC uses premium dollars to satisfy its benefit guarantees.

Under Alternative $\mathrm{C}$, an employer would still be permitted to terminate a plan voluntarily, but if the employer remains in business the obligation of the employer to make contributions for unfunded vested benefits would continue. ${ }^{63}$ A termination would occur when the plan

60. ERISA $\S 4062(\mathrm{~b})$.

61. Alternative $B$ would also significantly reduce the administrative expense presently incurred by the PBGC. For instance, the need for determining the net worth of an ongoing corporation would be eliminated.

62. "The main trouble with Alternative B is that there is now no way to terminate a planwhich is a matter not just of form, but of substance: there is no way to stop the vesting clock until vested benefits are fully funded." Comments of $\mathrm{H}$. Givens, supra note 44 , at 4.

63. The PBGC would not becone trustee of the plan and there would be no need to call 
was amended to provide that future service will no longer be credited for either benefit accrual or for vestimg purposes. The sponsor would thus be able to limit the benefits to be provided by the plan at their then vested levels. However, several other results would also stem from termination.

First, the plan's schedule for funding vested benefits would be accelerated to require fundimg within a reduced period, for instance ten years. ${ }^{64}$ When the plan's assets were sufficient to hquidate its obligations, ${ }^{65}$ a distribution could occur and the employer would have no further obligation to the plan or to the PBGC. Until that time, the sponsor would be required to contmue funding the plan on the accelerated schedule. ${ }^{66}$

Second, certam other technical adjustments would have to be made. The plan would also liave to be amended to provide for the cessation of benefit accruals attributable to future salary increases for employees whose interests are already vested. The sponsor would have to eliminate supplemental and ancillary benefits, such as death and disability benefits, for which the conditions precedent to entitlennent had not yet been fulfilled.

Following a voluntary termination, employers ceasing busmess operations would be expected to discharge their pension obligations as they would those of any other creditor. If the obligations could be met from the plan's or the employer's assets, the liquidating sponsor would have no further liability. If the business was liquidating, the pension plan claim would share in the liquidated assets of the business as a general creditor. If the plan's claim could not be satisfied in an amount sufficient to provide for guaranteed benefits, an msurable event would occur. The PBGC would becoine trustee and provide the guaranteed benefits.

Thus, under Alternative $C$, an insurable event occurs, with attendant PBGC involvement, only when the sponsor is financially unable to provide guaranteed benefits that participants are entitled to receive

upon premium dollars for benefit payments or administrative expense until the employer either became insolvent or went out of busimess.

64. "The essence of Alternative $C$ is to allow the vesting clock to stop if the sponsor wants it badly enough to pay for it by a faster pace of funding." Comments of H. Givens, supra note 44 , at 4.

65. The obligations could be liquidated through a purchase of annuities or through payment of lump sums, if permitted by the plan.

66. Following voluntary termination, if a plan sponsor found itself unable to meet its funding obligations under the alternative funding schedule, the sponsor could seek partial funding waivers. If the partial funding waivers proved to be inadequate rehef, the distressed sponsor could only resort to bankruptcy reorganization. See text accompanying notes 53-59 supra. 
under the plan. Normally, this inability will occur in the bankruptcy court in a reorganization or an insolvency proceeding. Direct PBGC involvement would then be limited to situations in which the sponsor is undergoing reorganization or liquidation and would not occur autoinatically on voluntary termination.

\section{The Comparative Merits of Alternatives $A, B$ and $C$.}

The alternatives to CELI all possess a certain common theine, namely, the deferral of sone (or ail) of the present consequences of voluntary termination. In the case of Alternative A, employer hability is deferred froin the date of plan termination to a schedule of yearly payments, and all other consequences of plan termination remain the same. ${ }^{67}$ If, during the period of deferred payment, business hardship (primarily in the form of bankruptcy proceedings) should occur, additional rehef would beconne available. In the case of Alternative B, benefit reductions or plan termination would be permitted only during bankruptcy reorganization, and thus, access to termination would be related to business hardship or plan sufficiency. Alternative $C$ is an intermediate approach that permits the elimination or reduction of certain plan benefits prior to business hardship, but limits PBGC involveinent to an insurable event that inay occur at a later date.

Althougl Alternative A shifts the focus of the PBGC's financial assistance away from plan termination to business hardship, as evidenced by bankruptcy or insolvency, the proposal raises two concerns. First, readily available time payments for employer liability may induce terminations by strong employers in plant shutdown and liquidation situations, particularly where there is a substantial difference between vested liabilities (as in a frozen plan) and guaranteed liabilities (as in a terminated plan). ${ }^{68}$ Such induced terminations could bring with thein unnecessary benefit losses for plan participants. Second, the Panel's approach would have little impact on the cost of PBGC's case processing operations and of the ongoing administration of plan assets and benefits. ${ }^{69}$

67. For instance, the present restriction to guaranteed benefits for participants and the provisions for PBGC trusteeship and benefits administration would remain applicable.

68. In other words, by terminating under Alternative A, a sponsor could reduce its obligations under the plan from the promised level of benefits to the guaranteed level of benefits without incurring any special penalty, since the sponsor's annual obligation to the plan would be approximately the same before and after the termination. See notes 39-40 supra and accompanying text.

69. The administrative burden that plan terminations have placed upon the PBGC is significant. Between July 1, 1978 and September 30, 1978, the PBGC opened 1,002 plan termination cases while closing 1,284 plan termination cases. At the end of that period, the PBGC was serving 
Alternative B builds upon the Panel's proposals. It attempts to reduce unnecessary benefit losses to participants and to delay the administrative involvement of the PBGC in situations in which the employer is financially capable of meeting its minimal responsibilities to the plan. Alternative B could be expected to have a significant impact on both the private pension system and the termination insurance program. ${ }^{70}$ However, Alternative B has been viewed to possess certain disadvantages. Probably the inost significant is Alternative B's impact on an einployer's finances and accounting procedures. Making pension habilities the equivalent of an employer's legal obhgations might aggravate the issue of whether such habilities should be disclosed as "full fledged" corporate liabilities on the balance sheet or be reflected in the footnotes. ${ }^{71}$

There is solne apprehension that requiring the inclusion of pension liabilities on the balance sheet as a hability could create unforeseen disruptions in the financial affairs of many companies by, among other things, placing thein in violation of existing indenture agreements and loan covenants. Depending on the treatment of such habilities on the income statement, significant reductions im reported income imight also result. Beyond these concerns lies the broader question as to the impact of sucl "new" balance sheet liabilities on the availability and cost of capital. While lenders and securities analysts are already paying more careful attention to currently footnoted pension liabilities, it is unclear whether elevating such liabilities will affect their evaluation of a business.

Other areas that raise concerns include, for example, the impact of the alternative proposals on plan formation and benefit improvements, especially for small einployers and smaller plans. These alternatives niay not inake defined benefit plans nore attractive to small employers, and thus niay not bring defined benefit coverage to workers not currently covered under sucli private plans. ${ }^{72}$

as trustee for 266 terminated plans. PBGC Fourth Quarter Bulletin, reported in [1975-1979 Transfer Binder] Pens. Plan Guide (CCH) \25,267.

70. Fewer plan terminations would mean fewer claims against the insurance systein and lower administrative costs to the PBGC. This, in turn, would help to keep premiun rates down.

71. The proper disclosure of pension habilities under the current law is presently a major issue within the private sector. Recent decisions on related issues and disclosure drafts issued by the Financial Accounting Standards Board suggests that the accounting profession itself may conclude that pension liabilities should be reported as real corporate habilities. This issue nay very well be decided without considering the potential effects of adopting alternatives A, B or C.

72. For example, the elimination of voluntary termination for the ongoing sponsor in Alternative $B$ has provoked the following criticisin:

Plans are terminated for many reasons, none of which, fortunately, has yet to require justification to the PBGC or other governmental agency. The day when such justifica- 
The main difference in the various formulations of employer hability under Alternatives A, B and C concerns the amount of freedom given solvent employers in dealing with benefit problems. Alternative C maintains the flexibility presently available to employers under ERISA (for instance, the ability to eliminate non-vested benefits by terminating under the current statute) but takes away the freedom to transfer to a government agency the responsibility for administering plan benefits and for assuming investment risks. Alternative $\mathrm{C}$ also attempts to respond to the financial and accounting concerns raised by Alternative $B$ by defining the events that trigger "legal" hability im terms of business termination, voluntary plan termination, filing for bankruptcy, or some other critical event, rather than at the dates the benefits accrue.

\section{E. The Feasibility of Insolvency Insurance: The Foreign Experience.}

Insolvency msurance may be a practical alternative to the present coinbimation of plan termination imsurance, imposition of employer hability and the origimally proposed program of contingent employer liability insurance. Several foreign countries, notably West Germany and Sweden, have insolvency insurance programs in effect at the present time. ${ }^{73}$ The experience of these two countries, thus far, demonstrates not only that insolvency insurance may be a feasible method of providmg protection to plan participants, but also that such protection can be maintained largely through the efforts of the private sector.

In both West Germany and Sweden, under enabling legislation, private mdustry formulated and now administers their pension insurance programs. ${ }^{74}$ The method of funding pension plans, the approach

tion will be required will be the day when no more plans are created and no more benefits are liberalized. In a free market, economic resources are allocated to what is perceived, rightly or wrongly, to be the most effective use; if an employer concludes that the game is no longer worth the candle, he must be free to bring his plan to an end.

What you cannot get out of, you will never voluntarily enter into.

Comments of $\mathrm{H}$. Givens, supra note 44 , at 9.

On the other hand, all three alternatives eliminate the threat of immediate imposition of employer liability upon termination. ERISA \$ 4062. In one survey, 38.3\% of the terminating employers responding reported that this potential liability had a "very large" effect on the decision to terminate, $19.6 \%$ reported a "moderate" effect on the decision and $30.1 \%$ reported "little or no" effect on the decision. A large percentage of the responding sponsors were small employers with relatively small plans. SubCOMM. ON SBA AND SBIC Legisiation AND GenERAL SMALl BusiNess Problems of the House Comm. on SMall Business, ERISA Questionnaire Results (1977), reprinted in [1975-1979 Transfer Binder] Pens. Plan Guide (CCH) I 25,194. To the extent the alternatives eliminate the "one-shot" liability, the attractiveness of pension plans may be enhanced.

73. See Roper, Germany-New Legislation on Employee Benefits, BENEFITS INT'L, Mar. 1975, at 10, 11; Book Reserve Or Insurance Is Permitted For Financing Swedish Pension Benefits, EMPloyee Benefit Plan Rev., Feb. 1979, at 44.

74. See Roper, supra note 73, at 10; Swedish Pension Benefits, supra note 73, at 44. 
to plan termination and the method of providing termination imsurance for plan participants are quite different from the methods under ERISA but may be worthy of consideration as alternatives to present practices in the Umited States.

Most employers in West Germany and Sweden are permitted to finance their pension promises through the "book reserve" method of funding. ${ }^{75}$ This method of funding involves annual transfers on a company's incoine statement and balance sheet to reflect amounts set aside to cover past accrued and currently accrning benefits. These transfers are tax deductible by the employer at the time they are made under regulations specifying the method of calculating the transfers. ${ }^{76} \mathrm{Al}-$ though the tax advantages accrue to the employer at the time the reserves are created, actual payment of benefits to retirees is deferred until the benefits become due. ${ }^{77}$

The book reserve method enables an employer to retain the moneys necessary to fund its pension obligations and to use them to finance its own growth and development. Book reserves were origmally imtroduced in West Germany as a means of easing the cash flow and capital problems of private industry following the devastation of World War II. ${ }^{78}$ Similarly, Sweden permits book reserve funding, under more stringent requirements than West Germany, ${ }^{79}$ as a catalyst for the forination of private pension plans and as a retained source of capital for private industry development. ${ }^{80}$

Book reserve funding consists of an adjustment on the books of an employer, and the integrity of any particular book funded plan may ultimately depend upon the business fortunes of the employer. However, it does comprise prefunding of the plan to the extent that the einployer's assets are earunarked for satisfaction of pension plan obligations. The difference between book reserve funding and the present systein of funding used in the Umited States is that nnder book reserve funding the pension plan assets are invested in the einployer's own business, ratlier than diversified by investment in a variety of other businesses. Obviously, there are hazards in the lack of diversification

75. Not all employers in countries that permit book reserving have unrestricted access to such methods of funding. For instance, in Sweden an employer unust undergo an initial credit check and subsequent reviews every five years in order to finance its plan through book reserves and be eligible for insolvency insurance. See Swedish Pension Benefits, supra note 73, at 44-45.

76. See Irons, Book Reserving in Germany-The Use of Insurance, BENEFITS INT'L, Apr. 1977 , at 6, 7.

77. Id. See also, Furer \& Rossler, Profile on Germany, BeNEFITS INT'1, Nov. 1976, at 7,11.

78. Furer \& Róssler, supra note 77, at 11.

79. See note 75 supra.

80. See Swedish Pension Benefits, supra note 73, at 46. 
of such investment risk. ${ }^{81}$

To protect employees agamst exposure to loss of benefits under a book reserve sytem, the German and Swedish systems provide insolvency imsurance for employees. Unlike the present system of plan termination insurance under ERISA, these continental insolvency insurance systems are administered by nongovernmental imsurance companies. A pool of private insurers offers single premium annuities for entitled employees whose employers become imsolvent. All employers maintaining plans in those countries and who use the book reserve system pay premiums that are available to purchase the annuities for employees whose insolvent employers are unable to continue their plans. ${ }^{82}$

Concomitant with allowing book reserve funding and providing private insolvency insurance under the Swedish and West German pension plan systems, employers are expected to continue their private pension plans once instituted. Contrary to the freedom under Title IV that American employers now have to terminate or cease future benefit accruals under plans that they sponsor, ${ }^{83}$ the foreign employers must continue accruals under their plans until they become insolvent and go out of business.

There are differences between the German and Swedish programs. For example, in Germany, all plans using the book reserve method are obligated to pay premiums for insolvency imsurance and their employees become automatically covered by annuities furnished by a consortium of private insurers if their employer becomes insolvent. ${ }^{84}$ On the other hand, in Sweden, an employer may use the book reserve method if the private insurance pool decides, on a risk assessment basis, to make insolvency insurance available to that employer.

For purposes of exploring the feasibility and desirability of an insolvency approach to plan termination insurance in this country, it is

\footnotetext{
81. It has been noted that

[i]f booking were the mandatory practice here, it would clearly lead to a less effective use of funds overall, since not every plan sponsor has equal economic use for them. If book reserving were optional here, it could in some instances reduce the cost of acquiring capital for sound business expansion, but at the risk of making too easy in other circumstances the use of funds in ventures that are either less rewarding or less sure. This "Balkanization" of the sources of investment capital can ouly impair markedly the efficiency of the present deep capital markets of the United States, which are unique in the world, with no prospect of anything but overall impairment of the investmeut return on peusion funds, and on all other funds as well.
}

Comments of $\mathrm{H}$. Givens, supra note 44, at 7-8.

82. See Roper, supra note 73, at 11; Swedish Pension Benefits, supra note 73, at 44. doin.

83. See ERISA $\S 4041$. Of course, collective bargaining agrcements may restrict this free-

84. See Furer \& Rössler, supra note 77, at 11. 
only pertinent to note that soine form of book reserve funding by einployers might be appropriate if termination insurance under ERISA was primarily available only in insolvency situations. W-ith termination insurance accessibility so restricted, some greater flexibility in retention of pension assets for internal use and development than that now perumitted under ERISA ${ }^{85}$ might compensate employers, to some extent, for surrender of their present easy access to termination. A partial book reserve system or increased allowable investment in employer securities or assets might be acceptable in such a context. Controls, other than those currently imposed by funding and fiduciary standards under the present provisions of ERISA, could be devised for such relaxation of the current restrictions on self-investment of plan funding.

Such an alteration in present fundimg requirements would not divert pension assets froin the private investment sector. To the extent that book reserve funding would be available, a percentage of a plan's assets would not be available for diversified placement in the entire spectruin of investment opportunities, but the assets would remain in the private sector as additional retamed capital for the particular einployer sponsoring the plan. This approach might serve as an incentive for responsible employers to mstitute plans or improve benefits in existimg plans.

\section{The Future of Plan Termination Insurance}

The possible legislative inodifications of Title IV presently under study by the PBGC may be vital to the contmuance of the private pension system. Plan termination imsurance for employees, in one form or another, is here to stay. ${ }^{86}$ The private pension system could become part of an overall governmental program akin to social security, or it could remain within the discipline and control of the private pension community. The interests of employees, employers and the entire business community suggest that a common effort is essential to the preservation of the private system.

The PBGC would welcome participation, or even preemption, by private carriers of the responsibility for the termination insurance program. Private insurer participation in an imsolvency insurance program could return the defined pension plan termination imsurance program, in large part, to the private sector where the program belongs. With the sanctions imposed by Titles I and II of the Act, most ongoing plans

85. See ERISA § 407.

86. Although Congress is considering several legislative proposals concerning ERISA, none of them would alter the concept of plan termination insurance under Title IV. 
should, in the long run, maintain the financial integrity necessary to provide their promised pension benefits and thus make the insurance risk acceptable to private underwriters. It is conceivable that the PBGC, which is now a self-financed government corporation, could eventually be transformed imto a nonprofit membership corporation ${ }^{87}$ and becoine a major insuring or comsurnig vehicle for furnishing such coverage in conjunction with other private insurers.

In order for the insolvency insurance approach to plan termination insurance to work, employers inust regard their pension commitments as part of their total wage package and treat thein as they would all other ongoing business obligations. The pension commitunents should be inet so long as the employer can do so financially. Employees inust be prepared to accept a scaling-down of their defined benefit expectations to lower levels as a trade-off for continued employment when their jobs are jeopardized by their employer's financial difficulties. The business community in general inust recognize the potential loss of private investment capital that would result froin the replacement of the private pension systein with a government program confined to Treasury investments and financed through tax revenues.

While the insolvency approach and its accompanymg commitment to the plan by ongoing employers may mitially seein radical and may possibly make defined benefit plans less attractive to smaller employers, there may be compensating advantages to the greater body of employers in such a proposal. By enforcing pension obligations of ongoing einployers, either on a full or curtailed basis, the program would encourage greater discipline on the part of employers in making and fundimg pension promises. Employers would have to appraise reahstically their current and prospective business posture when they institute or improve defined benefit plans. While this nay result in some teinporary abatement in the rate of new plan fornuations and of benefit improvements in existing plans, the integrity and reliability of all plans will be strengthened, and in the case of ongoing employers, the number of plan terminations should decrease substantially. The risk of abuse of the prograin through unnecessary or unwarranted terminations should diminish markedly. Fewer terminations will inevitably reduce claims against the termination insurance program, and the decreased case load will lower administrative costs for the program. This should result in lower insurance premiunus for responsible employers and a strengthened private defined pension benefit system.

87. A similar corporation is the Securities Investment Protection Corporation (SIPC) that insures customers of financially troubled brokerage houses. See 15 U.S.C. $\$ \S 78$ aaa-Ill (1976). 
For employees, such reenforced commitment of employers to their plans enhances the prospect of contimumg plans at their present or perhaps curtailed levels imstead of complete termination and possible loss of all vested benefits not guaranteed by the PBGC. The mcreased likelihood of contmued employment by ongoimg employers should more than counterbalance the possible dimunition im benefit expectations for employees of such employers. ${ }^{88}$ If the plan is insufficient and must ultimately be taken over by the PBGC, the employee would still be assured of receiving guaranteed benefits and might receive more under a curtailed, frozen or "voluntarily termmated" plan under Alternative C than from a terminated plan under the present program.

Apart from its role as a sponsor of pension plans, the busmess world has another interest in the preservation of a privately managed pension system in the United States. Both trusteed and insurancefunded plans control assets in the ever mounting hundreds of billions of dollars and have provided an essential source of imvestment capital for industry. ${ }^{89}$ A change in the present program that would serve to strengthen the integrity of the private pension system and to contimue the presence of that vast pool of investment dollars in the private sector deserves serious consideration by the busmess community. A switch to a government-administered retirement system would remove most, if not all, of those dollars from the private investment arena and relegate them to the coffers of the United States Treasury in one form or another. $^{90}$ If the performance of government-controlled retirement systems to date is any guide, there have been very few pre-funded assets in such plans that would be available for any form of investment prior to their required utilization for the payment of benefits. Finally, governmental administration and control of all retirement programs would inevitably increase regulatory intrusion into the busmess operations of the private sector.

88. In the case of some marginal employers, busimess shutdowns may occur if the employer must continue contributions and cannot scale down or discontinue pension accruals to lower contribution costs.

89. See Assets of $P \& I$ 1,000 Exceed $\$ 353$ Billion, Pensions \& Investments, Jan. 1, 1979, at 1 , col, 1.

90. Under the existing statute, which would not be altered in this regard by the proposed modifications, premiums payable under the program must be deposited in revolving funds in the Treasury Department and may not be invested in anything but Treasury fioated or Treasury guaranteed issues. ERISA $\S 4005(b)(3)$. It can be anticipated that under an overall government retirement program such a policy would mevitably be applied to all funds necessary to sustain the system. 


\section{CONCLUSION}

The PBGC has from its inception considered one of its inost important functions to be the administration of Title IV in a manner that would best serve to strengthen the private pension systein. The Corporation has maintained an "open-door policy" of consulting with representatives of the private sector concerning major policy questions and specific case probleins. At a time when the workability and desirability of a domestic private pension system is being seriously questioned, the PBGC and the private pension community should intensify the exchange of ideas and ultimately coalesce them into proposals to the Congress that will best serve "to encourage the contmuation and maintenance of voluntary private pension plans for the benefit of their participants."91 As the single most important source of capital in the investinent market, a strong private pension system can effectively create jobs and fight inflation. It is essential to the interests of botl employers and employees that ERISA work as intended by Congress. ${ }^{92}$

91. ERISA \& 4002(a).

92. The foregoing observations are not intended to represent an official position of the PBGC. They have been expounded primarily for the purpose of eliciting from the private pension community its views, positive or negative, and, nore importantly, its suggestions for other possible legislative modifications or perhaps its preference for maintenance of the status quo of the present program. 


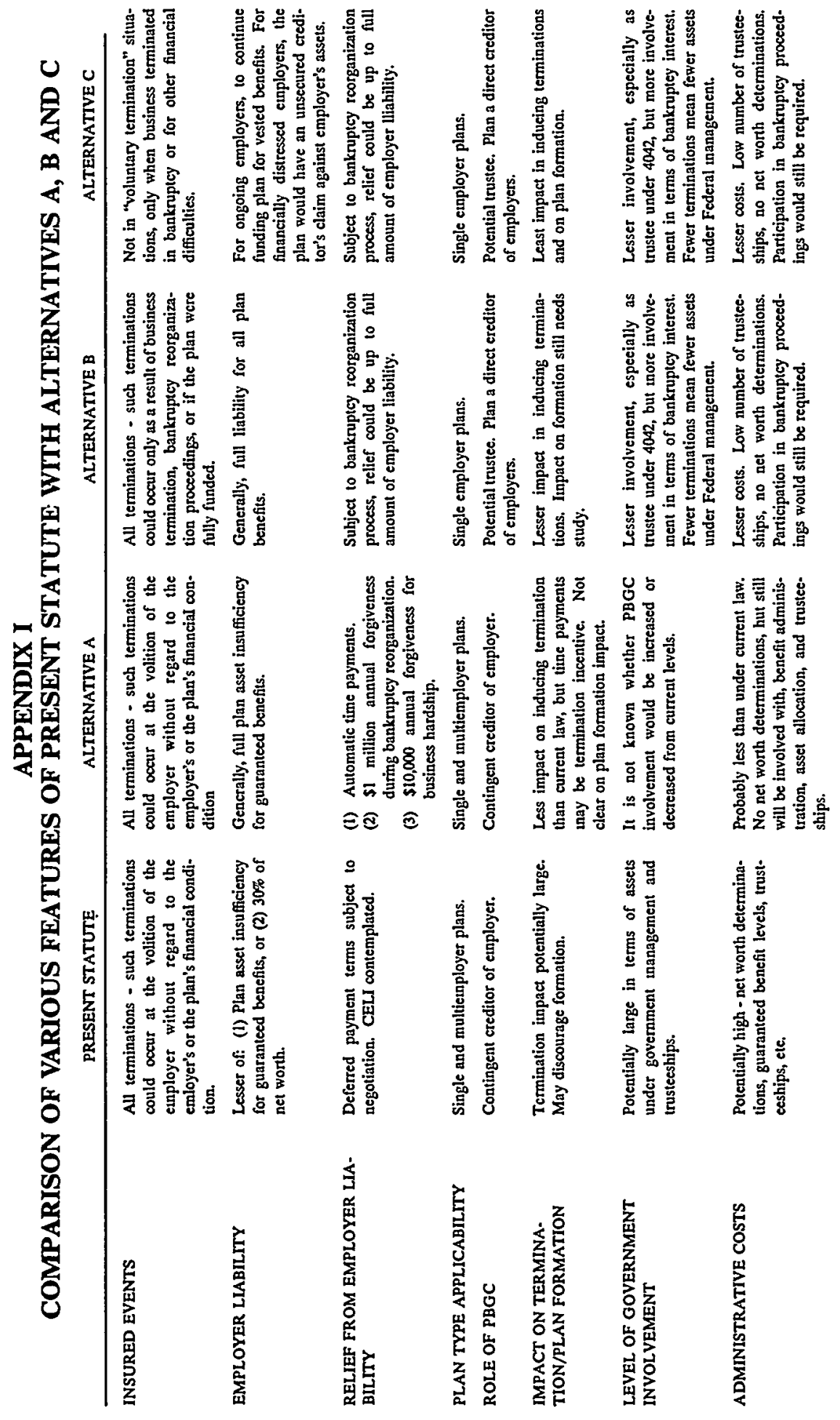

